Ambiente \& Água - An Interdisciplinary Journal of Applied Science
ISSN 1980-993X - doi:10.4136/1980-993X
www.ambi-agua.net
E-mail: ambi.agua@gmail.com

\title{
Medium-term projection for the National Hydro-Electrical System using wavelets
}

\author{
ARTICLES doi:10.4136/ambi-agua.2583
}

Received: 21 May 2020; Accepted: 05 Oct. 2020

\section{Francisco Wellington Martins da Silva ${ }^{1^{*} \text {; }}$; Cleiton da Silva Silveira ${ }^{2}$; Antônio Duarte Marcos Junior ${ }^{3}$; João Dehon de Araujo Pontes Filho ${ }^{2}$}

\footnotetext{
${ }^{1}$ Instituto de Engenharia e Desenvolvimento Sustentável. Universidade da Integração Internacional da Lusofonia Afro-Brasileira (UNILAB), Rua José Franco de Oliveira, s/n, CEP: 62790-970, Redenção, CE, Brazil.

${ }^{2}$ Centro de Tecnologia. Departamento de Engenharia Hidráulica. Universidade Federal do Ceará (UFC), Avenida. Mister Hull, Campus do Pici, Bloco 713, Cep: 60440-970, Fortaleza, CE, Brazil. E-mail: cleitonsilveira@ufc.br, dehonambiental@gmail.com

${ }^{3}$ Centro de Ciências e Tecnologias. Universidade Estadual do Ceará (UECE), Avenida Paranjana, $\mathrm{n}^{\circ}$ 1700, CEP: 84030-900, Fortaleza, CE, Brazil. E-mail: duarte.jr105@gmail.com

*Corresponding author. E-mail: martinswellington29@yahoo.com.br
}

\begin{abstract}
The Brazilian energetic matrix is predominantly based on hydroelectric plants and its planning is very sensitive to climate variability in different time scales. Natural Affluent Energy (NAE) is an established planning tool to project different scenarios of possible energy production, especially in an integrated system. This work aims to fill a gap between short-term (seasonal/ interannual) and long-term (climate change) planning scales by realizing NAE medium-term projections for the Brazilian National Interconnected System basins. The historical NAE series provided by the National System Operator was used for the years 1931 to 2014. The series was divided into two periods: from 1931 to 2003 for verification, and from 2004 to 2014 for calibration. The Wavelets Auto-Regressive (WAR) model was applied from low- and medium-frequency bands. The band signal was analyzed and the NAE was projected for the years 2014 to 2024 . A relationship of the NAE variability with the Pacific Decadal Oscillation (PDO) climate index and the Atlantic Multidecadal Oscillation (AMO) was verified.
\end{abstract}

Keywords: medium-term projection, natural affluent energy, wavelets.

\section{Projeção a médio prazo para o Sistema Hidroelétrico Nacional utilizando wavelets}

\section{RESUMO}

A matriz energética brasileira é predominantemente baseada em hidrelétricas e seu planejamento é muito sensível à variabilidade climática em diferentes escalas de tempo. A Energia Afluente Natural (ENA) é uma ferramenta de planejamento estabelecida para projetar diferentes cenários de possível produção de energia, especialmente em um sistema integrado. Este trabalho visa preencher uma lacuna entre as escalas de planejamento de curto prazo (sazonal/ interanual) e longo prazo (mudanças climáticas), realizando projeções de médio prazo da ENA para as bacias do Sistema Interligado Nacional Brasileiro. As séries históricas de ENA fornecidas pelo Operador Nacional do Sistema foram utilizadas para os anos de 1931 a 2014. 
Francisco Wellington Martins da Silva et al.

As séries foram divididas em dois períodos: de 1931 a 2003 para verificação e de 2004 a 2014 para calibração. O modelo Wavelets Auto-Regressivo (WAR) foi aplicado a partir de bandas de baixa e média frequência. O sinal das bandas foi analisado e a ENA foi projetada para os anos de 2014 a 2024. Foi verificada a relação da variabilidade da ENA com o índice climático da Oscilação Decadal do Pacífico (ODP) e a Oscilação Multidecadal do Atlântico (OMA).

Palavras-chave: energia natural afluente, projeção de médio prazo, wavelets.

\section{INTRODUCTION}

The consumption of goods and services associated with the advancement of technology, and the increase of the technologically active population, has increasingly demanded the use of more energy (ANEEL, 2017). Currently, Brazil has an energetic matrix that is predominantly renewable in terms of electricity production and, although it has tremendous environmental benefits, this category is known for its volatility due to climatic influence. This is a vulnerability of the energetic system, especially when it is too concentrated in one form of electricity production, such as in Brazil, where over $66 \%$ of total energy is generated by hydroelectric plants (EPE, 2011). The electrical generation by hydroelectric plants is highly dependent on climatic phenomena and, above all, good planning. Climate variability occurs at multiple time scales and affects decision making on water use.

Climate external forces such as El Niño, La Niña and Pacific Decadal Oscillation (PDO) contribute to natural inflows variability in the Brazilian electric sector, and consequently the power generated in hydroelectric plants. Knowing the behavior of these phenomena can greatly aid efficient and mitigating energy planning.

Many kinds of research had studied climate forces and their influence on hydrological variables. Studies such as Carvalho et al. (2004); Kodama (1993); Lazaro (2011) relate the Intertropical Convergence Zone (ITCZ) and the South Atlantic Convergence Zone (SACZ) with changes in rainfall in the SIN basins and the direct modification of the flow regime, impacting the Natural Affluent Energy (NAE), which is a direct product of hydroelectric productivity and streamflows.

Silva and Galvíncio (2011); Dantas (2012); Nascimento Júnior and Sant'Anna Neto (2016) showed that there is a relationship between interannual phenomena such as El Niño and the Atlantic dipole, modulated by low-frequency climatic phenomena, such as the Pacific Decadal Oscillation (PDO) (Mantua et al., 1997) and the Atlantic Multidecadal Oscillation (AMO) (Silva, 2013). Andreoli and Kayano (2005) identified a direct relationship of the El Niño episode in the positive phase of PDO and a higher occurrence of La Niña in the negative phase of PDO. The relationship between AMO and PDO influenced the total annual precipitation of the Western Amazon (Silva, 2012). According to Dantas (2012) rainfall and river flows in the Amazon and the Northeast present inter-annual variability and interdecadal time scale, which are more important than increasing or decreasing trends.

The statistical characteristics of a hydrological variable of a set of years or decades depend on both natural climate variability and anthropogenic forces. Decade-long climatic projections should try to bridge the gap between seasonal/interannual forecasts with deadlines of two years or less and project climate change a few decades ahead (Cane, 2010). There is no widely accepted theory for this type of projection; however, the decadal behaviour of Atlantic and Pacific Sea Surface Temperature (SST), AMO and PDO, can be introduced in projections of rainfall and streamflow to allow the consideration of low-frequency decadal variability. Kwon et al. (2007), considering the variability of temperature time series in England and rainfall in Florida, used a statistical model based on wavelet transform and observed that modelling was able to capture the memory of the low-frequency hydroclimatic series.

Rev. Ambient. Água vol. 15 n. 6, e2583 - Taubaté 2020 
Thus, this work presents a medium-term projection for the main basins of the National Interconnected System (NIS) from the temporal series of NAE, using wavelets to consider lowfrequency decadal variability.

\section{MATERIALS AND METHOD}

This work is divided into two main parts, according to Figure 1: (i) trend and variability analysis; followed by (ii) projections made for the entire electrical sector using wavelets. For this approach, trend/variability of the standardized annual series was analyzed by the following classical methods: 10-year moving average and Mann-Kendall-Sen (Burn and Elnur, 2002); and by wavelet transformation (Torrence and Compo, 1998), according to Equation 3. The wavelet-based model consists of the decomposition of time series into bands for all SIN basins for later use in the multivariate autoregressive model.

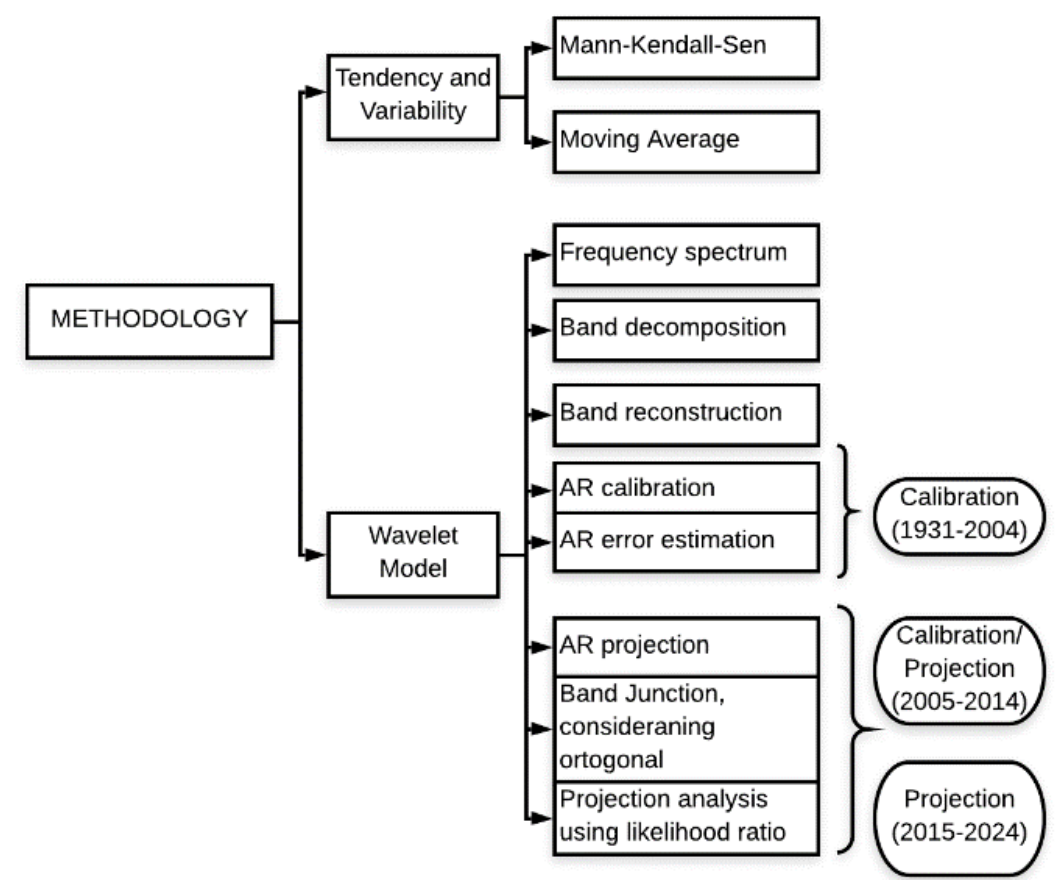

Figure 1. Methodology flowchart.

Data from NAE was made available by the National Electric System Operator (ONS) for the years 1931 to 2014. The series was divided into two periods; from 1931 to 2004 for calibration and from 2005 to 2014 for verification.

\subsection{National Interconnected System (SIN)}

The Brazilian electricity generation and transmission system is a large hydrothermal system with size and characteristics that allow it to be considered unique worldwide and have a strong predominance of hydroelectric power plants with multiple owners. Only $1.7 \%$ of the energy required by the country is outside the SIN, in small and isolated systems located mainly in the Amazon region (ONS, 2012).

The hydroelectric plants of the SIN are frequently built-in cascade systems (in the bed of the same river). Upstream plant operations interfere directly with downstream plant operations, so planning must be done in an integrated manner, increasing their complexity. The planning of the operation is done taking into account the operational interdependencies among the plants, as well as the interconnection among the subsystems. The SIN is divided into four subsystems: Southeastern/Midwestern Region, Southern Region, Northern Region and Northeastern Region. These Subsystems are interconnected by an extensive transmission network that 
enables the transfer of energy surpluses and allows the optimization of storage in the reservoirs of hydroelectric power plants and the integration of generation and transmission resources in the service to the total load of the system. (Ramos, 2011). Figure 2 shows the single-line diagram of the Grande and Paranaíba Basins as an example of a cascade model.

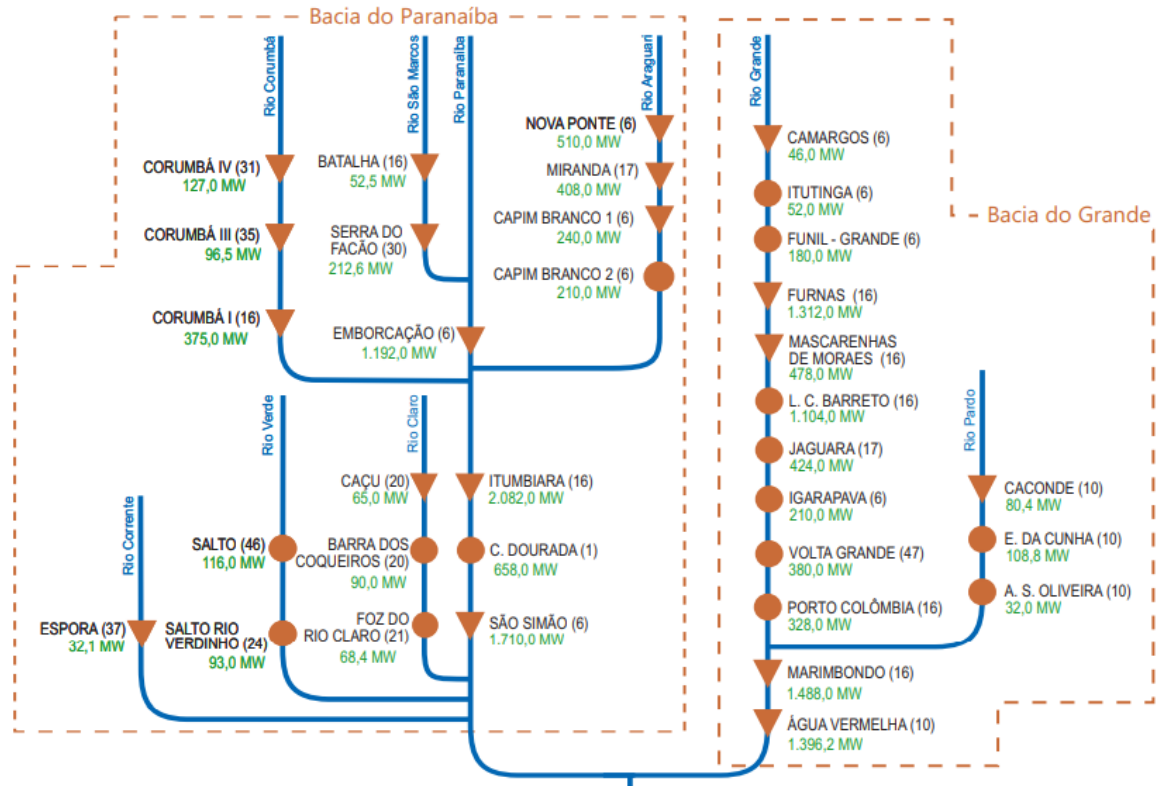

Figure 2. Hydroelectric use of the SIN in the Grande and Paranaíba

Basins.

Legend: The symbols $\rangle$, $\phi$ and $\rangle$ represent, respectively, a power plant with a reservoir; a power plant that has no water reservoir or has smaller or irrelevant dimensions; and a power plant under construction.

Source: ONS (2012).

\subsection{Natural Affluent Energy (NAE) Calculation}

An important variable in the hydroelectric planning framework is NAE, as it considers the interconnections between the different plants and watersheds from the monthly incremental flows of each hydroelectric station. It is obtained by multiplying the natural flow rate of each hydroelectric plant by its average productivity. Usually, the unit measure is $\mathrm{MW}_{\text {mean, which }}$ refers to the relationship between generated power and the facility operating time. It is calculated using the following Equations 1 and 2:

$$
\begin{aligned}
& \operatorname{NAE}_{\text {watersheds }}(t)=\sum_{i=1}^{n}\left[Q_{n a t}(i, t) \cdot p(i)\right] \\
& \operatorname{NAE}_{\text {subsystems }}(t)=\sum_{i=1}^{m}\left[Q_{n a t}(j, t) \cdot p(j)\right]
\end{aligned}
$$

Where:

$\mathrm{t}$ is the time interval considered for the NAE calculation;

$\mathrm{i}$ is the utilization of the system of the considered basin;

$\mathrm{n}$ is the number of stations in the system basin in question;

$Q_{\text {nat }}$ is the natural flow rate of the system in the time interval considered;

$\mathrm{p}$ is the average productivity of the turbine-generating set of the hydroelectric plant, referring to the fall obtained by the difference between the level of the amount, corresponding to storage of $65 \%$ of the useful volume, and the average level of the leakage channel; 
$\mathrm{j}$ is the utilization belonging to the utilization system of the subsystem considered; and $\mathrm{m}$ is the number of stations in the system.

Figure 3 (a) shows the basins whose NAE was estimated: Bacia Grande, Paranaíba, Paranapanema, Paraguai, Parnaíba, São Francisco, Tocantins, Doce, Uruguay, Jacuí, Amazonas, Paraná, Tietê, Iguaçu, Atlântico Suldeste, Atlântico Sul, Paraíba do Sul and Atlântico Leste. While Figure 3 (b) shows the subsystems.
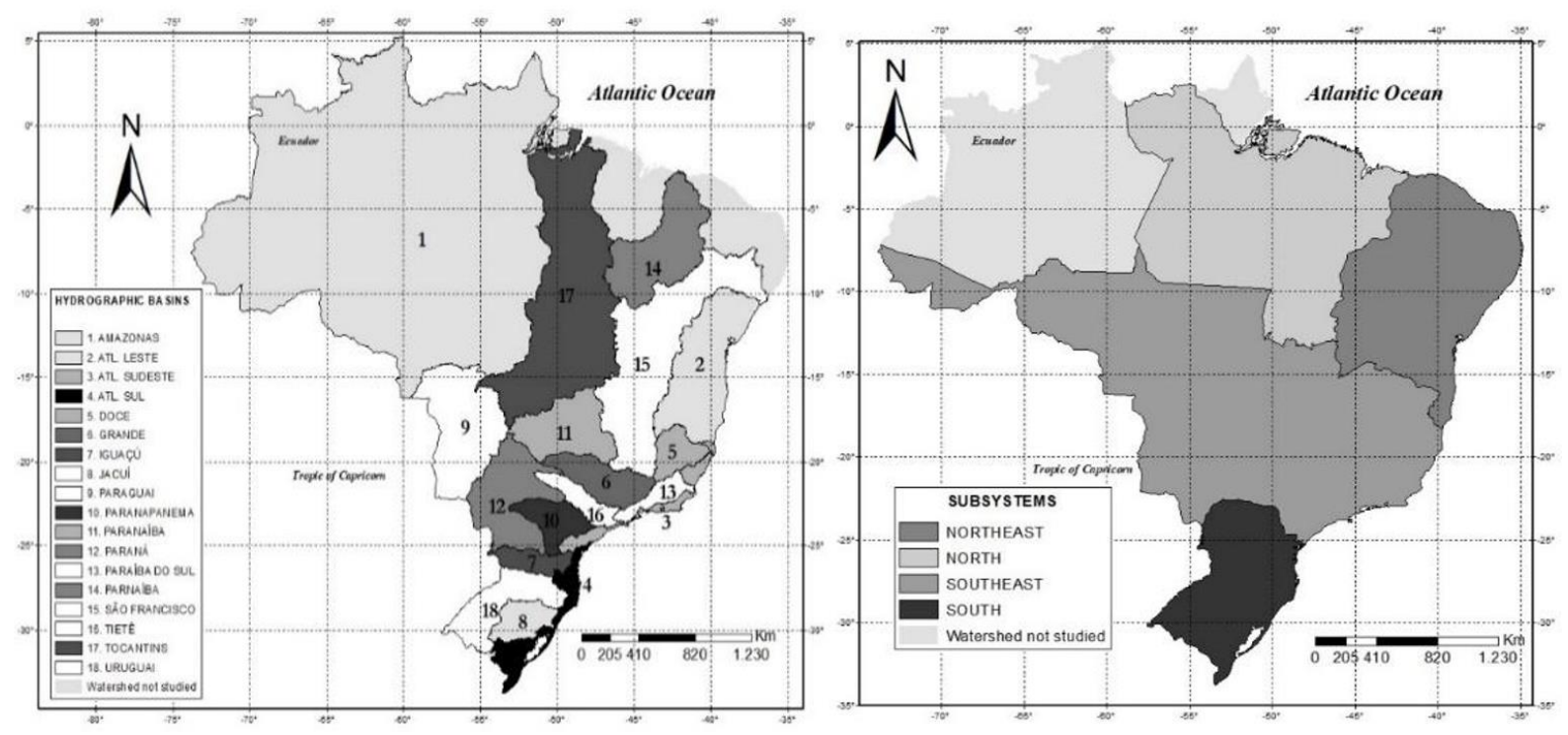

Figure 3. a) Hydrographic basins; b) Hydrographic subsystems.

\subsection{Mann-Kendall Test}

For the observed data $\mathrm{x}_{1}, \mathrm{x}_{2}, \ldots, \mathrm{x}_{\mathrm{k}}, \mathrm{x}_{\mathrm{j}}, \ldots, \mathrm{x}_{\mathrm{n}}$ of the NAE time series in the period from 1931 to 2014, the Mann-Kendall test was applied for a trend because the series is independent. To observe whether the variations of the series are independent and identically distributed, the test of the following hypotheses is considered:

i) $\mathrm{H}_{0}$ : There is no tendency if the observations of the time series are independent and identically distributed;

ii) $\mathrm{H}_{1}$ : There is a trend if the observations of the series have a monotonic tendency in time, that is, one of the variables increases or decreases its tendency.

Thus, the Mann-Kendall statistical test is given by Equation 3:

$S=\sum_{k=1}^{n-1} \sum_{j=k+1}^{n} \operatorname{Signal}\left(x_{j}-x_{k}\right)$

Where:

$x j$ and $x k$ are sequential values of NAE;

$\mathrm{n}$ is the size of the NAE time series;

The signal is the signal function.

$\operatorname{Signal}(x)=\left\{\begin{array}{cl}+1 & \text { if } x>0 \\ 0 & \text { if } x=0 \\ -1 & \text { if } x<0\end{array}\right.$ 


\subsection{Wavelets Auto-Regressive (WAR) Model}

Initially, the NAE series was standardized according to Equation 4.

$$
Z=\frac{X^{j}-\bar{X}}{\sigma}
$$

Where:

$\mathrm{Z}$ is the padronized variable;

$X^{j}$ is the annual variable NAE in a year $\mathrm{j}$;

$\bar{X}$ is the mean annual NAE of the historical series from 1931 to 2014;

$\sigma$ is the standard deviation of the Annual series.

The series decomposition in bands using Morlet Wavelet Function is performed in sequence, given by the Equation 5:

$$
\Psi_{0}(\eta)=\pi^{-1 / 4} e^{i \omega_{0} \eta} e^{-\eta^{2} / 2}
$$

With:

$$
\mathrm{w}_{0}=6 \text { e } \eta=\mathrm{t} / \mathrm{s}
$$

Where,

$\mathrm{t}$ is time;

$\mathrm{s}$ is the wavelet scale;

$\mathrm{w}_{0}$ is a non-dimensional frequency representing a wave modulated by a Gaussian envelope.

Three bands were used: one of high-frequency, of 1 to 10 years; one of medium frequency, from 11 to 33 years; and one of low-frequency of more than 33 years. Thus, the low-frequency band (Residual) was obtained by the Equation 6:

$N A E_{b b f}(i)=N A E(i)-N A E_{b a f}(i)-N A E_{b m f}(i)$

At where:

NAE (i) is the value of the average NAE in a year $i$;

$\mathrm{NAE}_{\text {baf }}(\mathrm{i})$ is the high-frequency band value ( 1 to 10 years) in a year $\mathrm{i}$;

$\mathrm{NAE}_{b m f}(\mathrm{i})$ is the medium frequency band value (11 to 33 years) in a year $\mathrm{i}$;

$\mathrm{NAE}_{\mathrm{bbf}}$ (i) is the low-frequency band value (from 33 years).

We say that $X_{t}, t Z \mathrm{~s}$ an autoregressive process of order $\mathrm{p}$ and we write $X_{t} A R(p)$ if we can write it: (Morettin, 2008) Equation 7.

$\mathrm{X}_{\mathrm{t}}=\phi_{0}+\phi_{1} \mathrm{X}_{\mathrm{t}-1}+\ldots+\phi_{\mathrm{p}} \mathrm{X}_{\mathrm{t}-\mathrm{p}}+\varepsilon_{\mathrm{t}}$

Where the estimation of the variable $\mathrm{Xt}$ for time $\mathrm{t}$ depends on a linear combination of $\mathrm{p}$ terms of the observed series, including the random term $\varepsilon(t)$ of white noise (estimation errors with normal distribution, mean zero, constant variance and non-correlated). The coefficients $\phi i$ are parameters that weight the values of $\mathrm{Xt}$, from the instant immediately preceding $\mathrm{t}-1$ to the farthest $\mathrm{t}-\mathrm{p}$, being determined through techniques to minimize error. 
With the decomposition of the bands from the transformed into wavelets, the signal was reconstructed by applying an autoregressive (AR) model to the high-, medium- and lowfrequency bands, considering that they are orthogonal as described by (Silveira, 2014). Given by Equation 8:

$z_{i}^{p}=\sum_{i=1}^{b} A R s_{b}(i)+A R s_{R(i)}(i)$

Where:

ARsb represents the autoregressive model of each high- and medium-frequency band.

ARsR represents the auto regressive model of the low-frequency band (residual).

The fundamental characteristic of an AR process is summarized in the fact that the current observation is correlated with the previous observation, that is, there is a significant correlation in the first lag, that is, between $\mathrm{Xt}$ and $\mathrm{Xt}-1$. Because $\mathrm{Xt}-1$ is also related to $\mathrm{Xt}-2$, there is indirectly a correlation in the second lag, between Xt and Xt-2. However, in the case of AR series, this correlation is implicit in the first lag (Moreira Junior and Caten, 2004).

\subsection{Model Evaluation: maximum likelihood}

After the composition of the normalized NAE series, an autoregressive model per band is used (Morettin, 2008). The error obtained during calibration is used in the projections. Through these, the mean and standard deviation of the errors are estimated, considering it as white noise. Further, the projection is obtained by summing the band's auto-regressive models.

After completion, the Wavelet Auto-Regressive (WAR) model is evaluated by applying the maximum likelihood estimated in a random sample $\mathrm{x}_{1}, \mathrm{x}_{2}, \ldots, \mathrm{x}_{\mathrm{n}}$ of the NAE time series, whose probability distribution depends on an unknown parameter $\theta$. The main objective is to find a point estimator $\mathrm{u}\left(\mathrm{x}_{1}, \mathrm{x}_{2}, \ldots, \mathrm{x}_{\mathrm{n}}\right)$ such that $\mathrm{u}\left(\mathrm{x}_{1}, \mathrm{x}_{2}, \ldots, \mathrm{x}_{\mathrm{n}}\right)$ is a "good" point estimate of $\theta$, where $\mathrm{x}_{1}, \mathrm{x}_{2}, \ldots, \mathrm{x}_{\mathrm{n}}$ are the observed values of the random sample.

Let $\mathrm{x}_{1}, \mathrm{x}_{2}, \ldots, \mathrm{x}_{\mathrm{n}}$ be a random sample of size $\mathrm{n}$ of the random variable $\mathrm{X}$ with density (or probability) function $\mathrm{f}(\mathrm{x} \mid \theta)$, with $\theta \in \Theta$, where $\Theta$ is the parametric space. The likelihood function of $\theta$ corresponding to the observed random sample is given by Equation 9:

$$
L(\theta, x)=\prod_{i=1}^{n} f_{Y_{i}}\left(x_{i} \vee \theta\right)
$$

The performance of projection of WAR in comparison to the climatology is calculated according to Equation 10:

$$
\text { Performance }=\left(\frac{L(\theta)_{\text {projection }}}{L(\theta)_{\text {climatology }}}\right)^{\frac{1}{n}}
$$

Where $\mathrm{n}$ is the number of years of the historical series used. When Performance $>1$, there was an improvement in the weather forecast. On the contrary, when Performance $<1$, there was a worsening of the projection.

\section{RESULTS AND DISCUSSIONS}

\subsection{Trend Analysis}

Trend analysis of NAE values was performed to detect if there is a trend and, if there is one, whether it is positive or negative. Figure 4 shows the results for the tests applied in historical data. Values above zero indicate the positive deviations (positive anomaly), where 
the annual NAE exceeded the historical average, and values below zero indicate the periods of negative deviation (negative anomaly), where NAE was lower than the mean historical information.

Analyzing the results of the moving average for the stations of the Southeastern Subsystem, it is possible to observe low-frequency variability with long periods of three decades. The Mann-Kendall test showed a positive trend in the NAE series. In the Northeastern Subsystem, a decadal variability is observed through the moving averages. The utilization of the Southern Subsystem showed a significant positive trend with year-on-year behaviour, in most of the series, the Mann-Kendall method shows a tendency of NAE increase. The utilizations of the Northern Subsystem presented anomalies between the ranges of -1 to 1 . Moving averages presented low-frequency decadal variability. The decades of the $40 \mathrm{~s}$ and $80 \mathrm{~s}$ were more energetic. The series showed no significant trend.
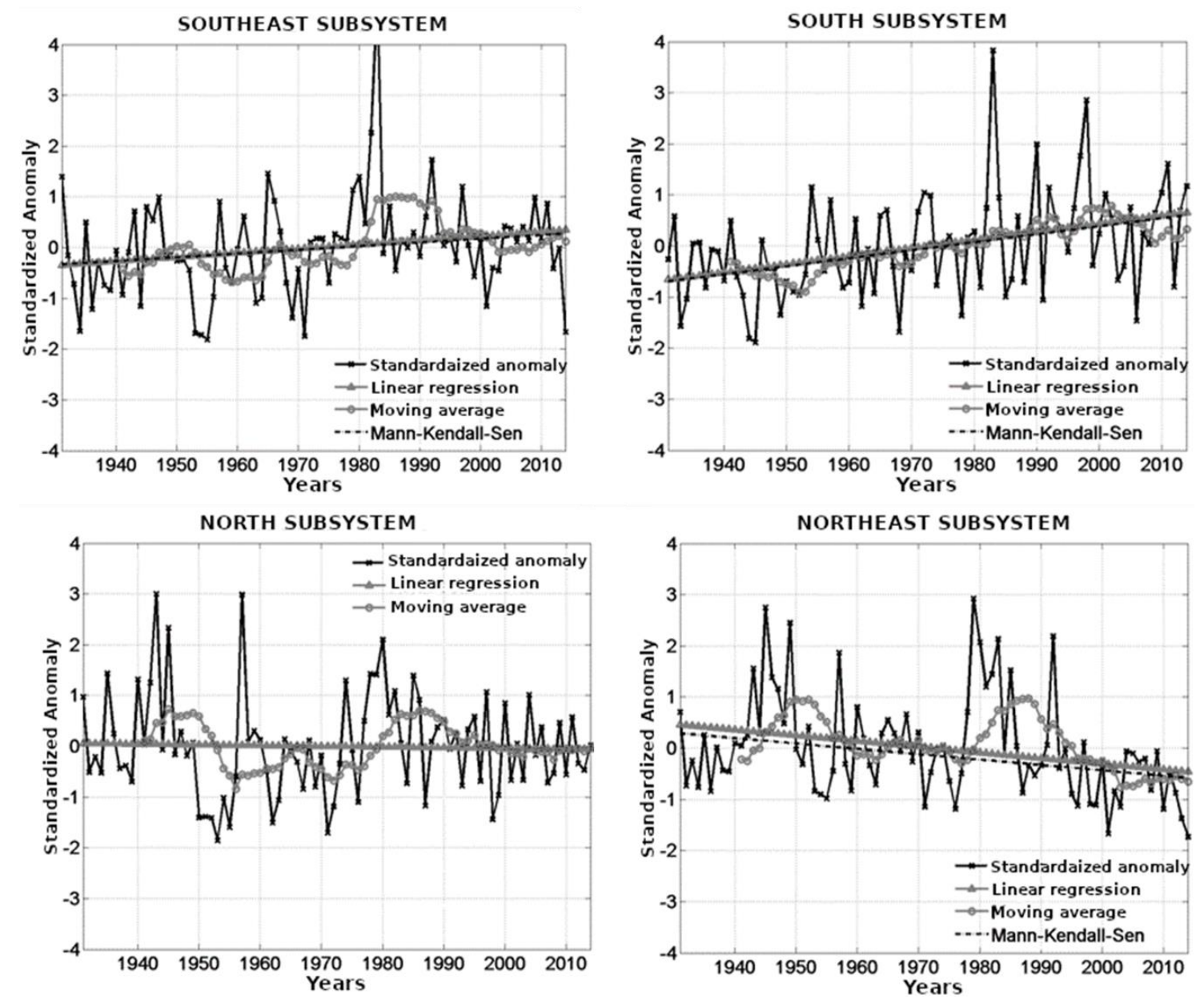

Figure 4. Trend analysis.

The trend analysis detected that thirteen out of eighteen basins analyzed in this study presented a significant trend, Mann-Kendall hypothesis test different from zero. Among these, nine registered a positive trend and four showed a negative trend. The positive trend group is composed of Atlântico Sul, Atlântico Sudeste, Iguaçu, Jacuí, Paraguai, Paraná, Paranapanema, Tiete and Uruguai Basins. Most of these basins belong to the Southern and Southeastern /Midwestern Subsystem. For the basins of the São Francisco, Paranaíba, Paraíba do Sul, Grande, and Amazonas Basins, the Mann-Kendall test showed no tendency, and for the Parnaíba, Tocantins, Doce and Atlântico Leste basins, the test presented a negative trend. Figure 5 and Table 1 show the results for the studied basins. 


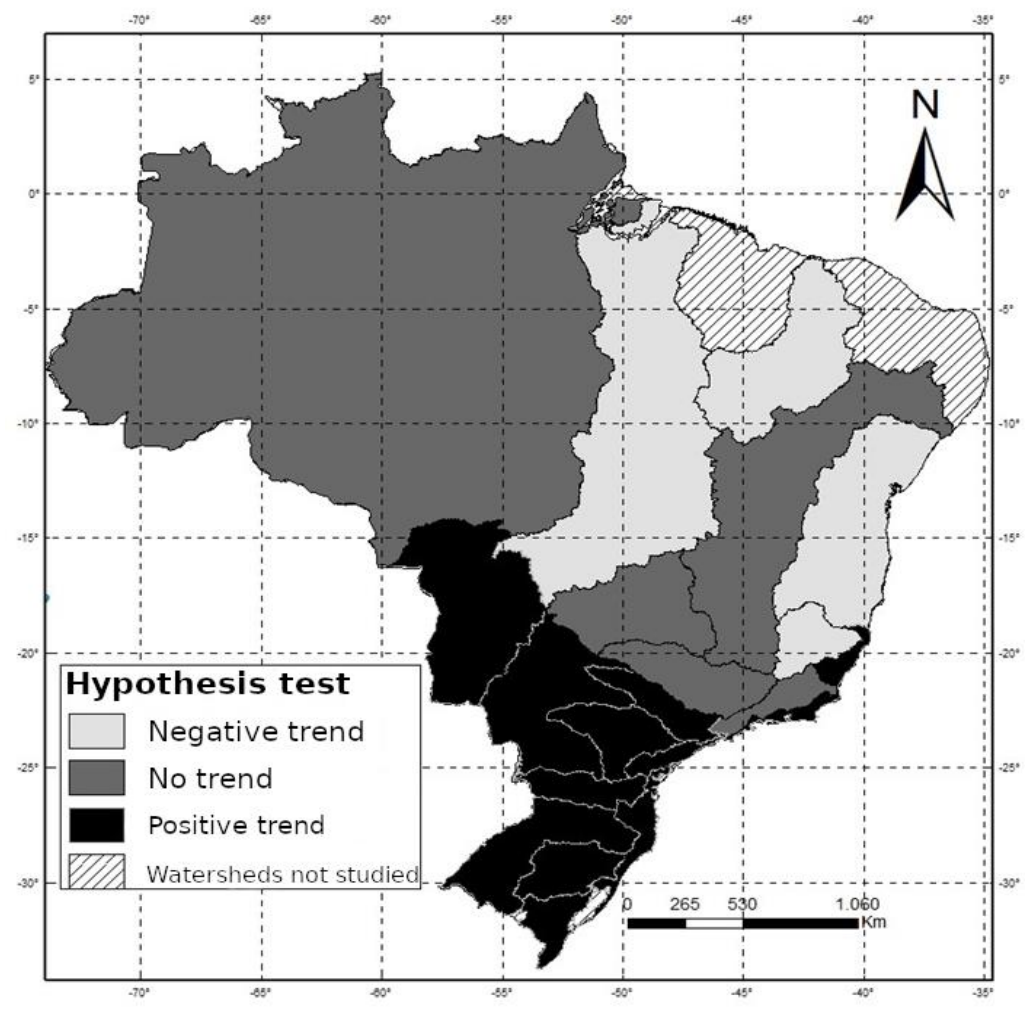

Figure 5. NAE Trend analysis for each basin.

Table 1. Mann-Kendall Test.

\begin{tabular}{cc}
\hline Basin & Trend \\
\hline Parnaíba, Tocantins, Doce and Atlântico Leste & Negative Trend (-1) \\
São Francisco, Paranaíba, Paraíba do Sul, Grande, and Amazonas & No Trend (0) \\
$\begin{array}{c}\text { Atlântico Sul, Atlântico Sudeste, Iguaçu, Jacuí, Paraguai, Paraná, } \\
\text { Paranapanema, Tiete and Uruguai }\end{array}$ & Positive Trend (1) \\
\hline
\end{tabular}

The analysis of the wavelet transformation for the study basins is presented in Tables 2, 3 and 4 and Figures 6 (a), 6 (b) and 6 (c) in the form of maps, showing the spatial distribution of variance proportions explained by the high-, medium- and low frequencies, respectively. With this information, it is possible to realize that a large part of the variance in all the basins is explained by the high-frequency band, less for that of Paraguai, and that, in general, the medium- and low-frequency phenomena are more relevant to the basins which are more embedded in the central part of the continent.

Table 2. High-Frequency (1 to 10 years).

\begin{tabular}{cc}
\hline Basins & Variance Percentage $\left(\boldsymbol{\sigma}^{2}\right)$ \\
\hline------- & $\sigma^{2}<10 \%$ \\
Paraguai & $10 \% \leq \sigma^{2}<20 \%$ \\
$\begin{array}{c}\text { Parnaíba, Tocantins, Doce, Atlântico Leste São Francisco, Paranaíba, Paraíba } \\
\text { do Sul, Grande, Amazonas Atlântico Sul, Atlântico Sudeste, Iguaçu, Jacuí, } \\
\text { Paraná, Paranapanema, Tiete and Uruguai }\end{array}$ & $20 \% \sigma^{2}<30 \%$ \\
\hline
\end{tabular}


Table 3. Mean Frequency (11 to 33 years).

\begin{tabular}{cc}
\hline Basins & Variance Percentage $\left(\boldsymbol{\sigma}^{2}\right)$ \\
\hline Paranaíba, Grande, Paraíba do Sul & $\sigma^{2}<10 \%$ \\
Paraguai, Paraná & $10 \% \leq \sigma^{2}<20 \%$ \\
Tocantins, Parnaíba, Paranapanema, Atlântico Sul & $20 \% \leq \sigma^{2}<30 \%$ \\
Doce, Atlântico Leste São Francisco, Amazonas, Atlântico Sudeste, & $\sigma^{2} \geq 30 \%$ \\
\hline Iguaçu, Jacuí, Tiete and Uruguai, & \\
\hline
\end{tabular}

Table 4. Low-Frequency (33 to 84 years).

\begin{tabular}{cc}
\hline Basins & Variance Percentage $\left(\boldsymbol{\sigma}^{2}\right)$ \\
\hline Tiete, Paranapanema, Atlântico Sul, Uruguai & $\sigma^{2}<10 \%$ \\
Parnaíba, Doce, Atlântico Leste, Paraíba do Sul, Amazonas, & $10 \% \leq \sigma^{2}<20 \%$ \\
Atlântico Sudeste, Iguaçu, Jacuí and Paraná & $20 \% \leq \sigma^{2}<30 \%$ \\
Tocantins, São Francisco, Paraguai, Paranaíba, Grande & $\sigma^{2} \geq 30 \%$ \\
\hline------- &
\end{tabular}
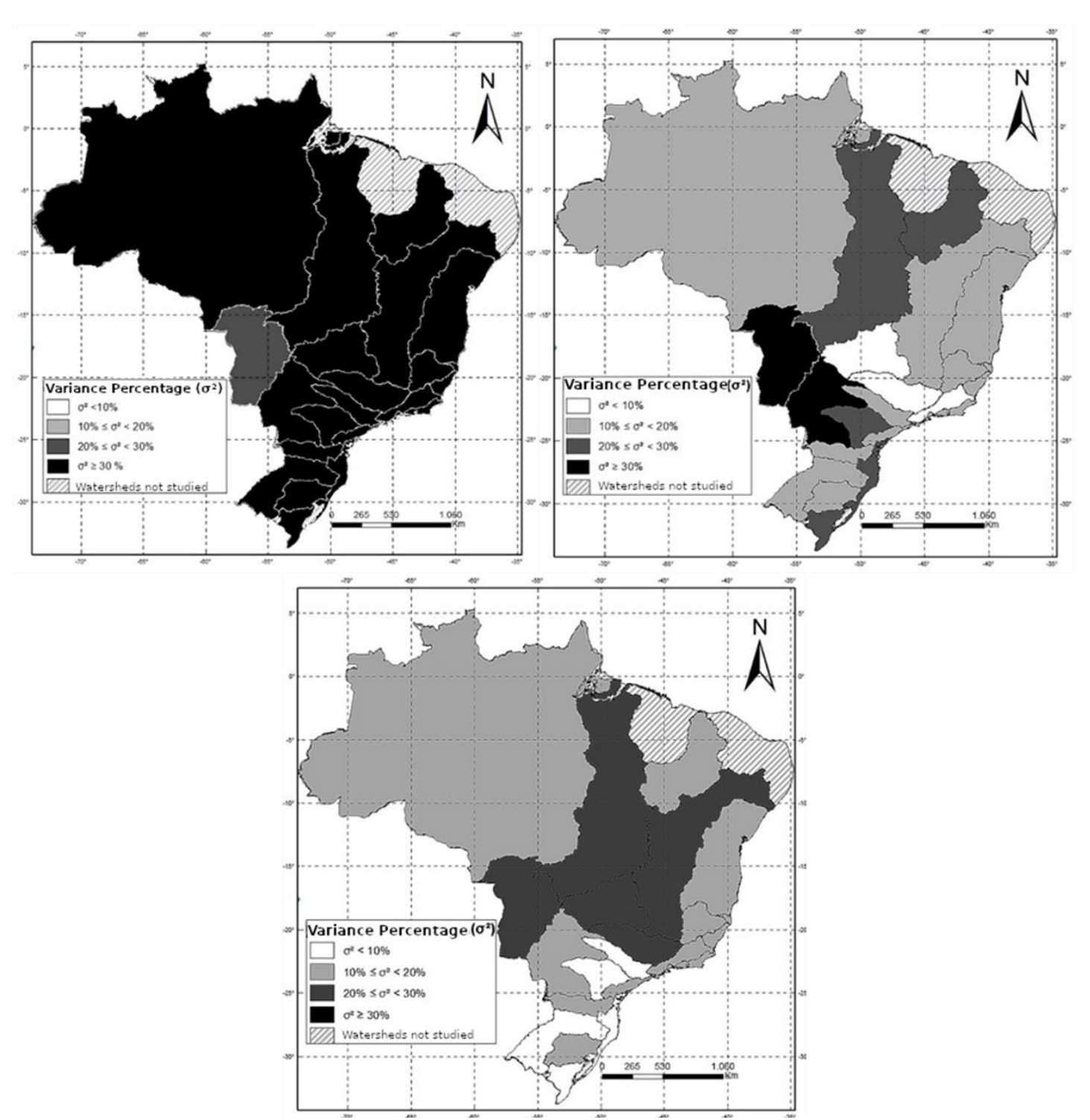

Figure 6. Spatial distribution of variance proportions explained by bands of: (a) highfrequency (1 to 10 years); (b) mean frequency (11 to 33 years) and (c) low-frequency - residue (34 to 84 years). 
Wavelet analysis for the subsystems from the decomposition of the frequency bands is presented in Figure 7. The Southeastern/Midwestern Subsystem presented significant variability. The low-frequency band (Residual) remained approximately constant until the 1960 period. In the period between 1970 and 2000, it presented its most energetic phase, presenting a possible relation with the AMO cold phase. The Northeastern Subsystem presented variation in the low-frequency band (Residual) of approximately 30 years. In the period 1931 to 1950, the time series shows the values of the standardized NAE index coincident with the PDO periods in the cold phase. In the Southern Subsystem, the low-frequency band (Residual) showed oscillation in a long period, changing phase around 1970, with a considerable peak in the decade of 1990. The period between 1970 to 2000 coincided with the AMO cold phase. The Northern Subsystem showed significant variability with maximum values between 1945 and 1980 in the bands, in those years the three bands were at coincident peak. In the Northern Subsystem and Southeastern Subsystem, there is a periodic oscillation in the low-frequency band with a period of approximately 30 years. This behaviour may be related to the PDO, where the hot phase coincides with the fewer periods and the cold phase with the more energetic periods.
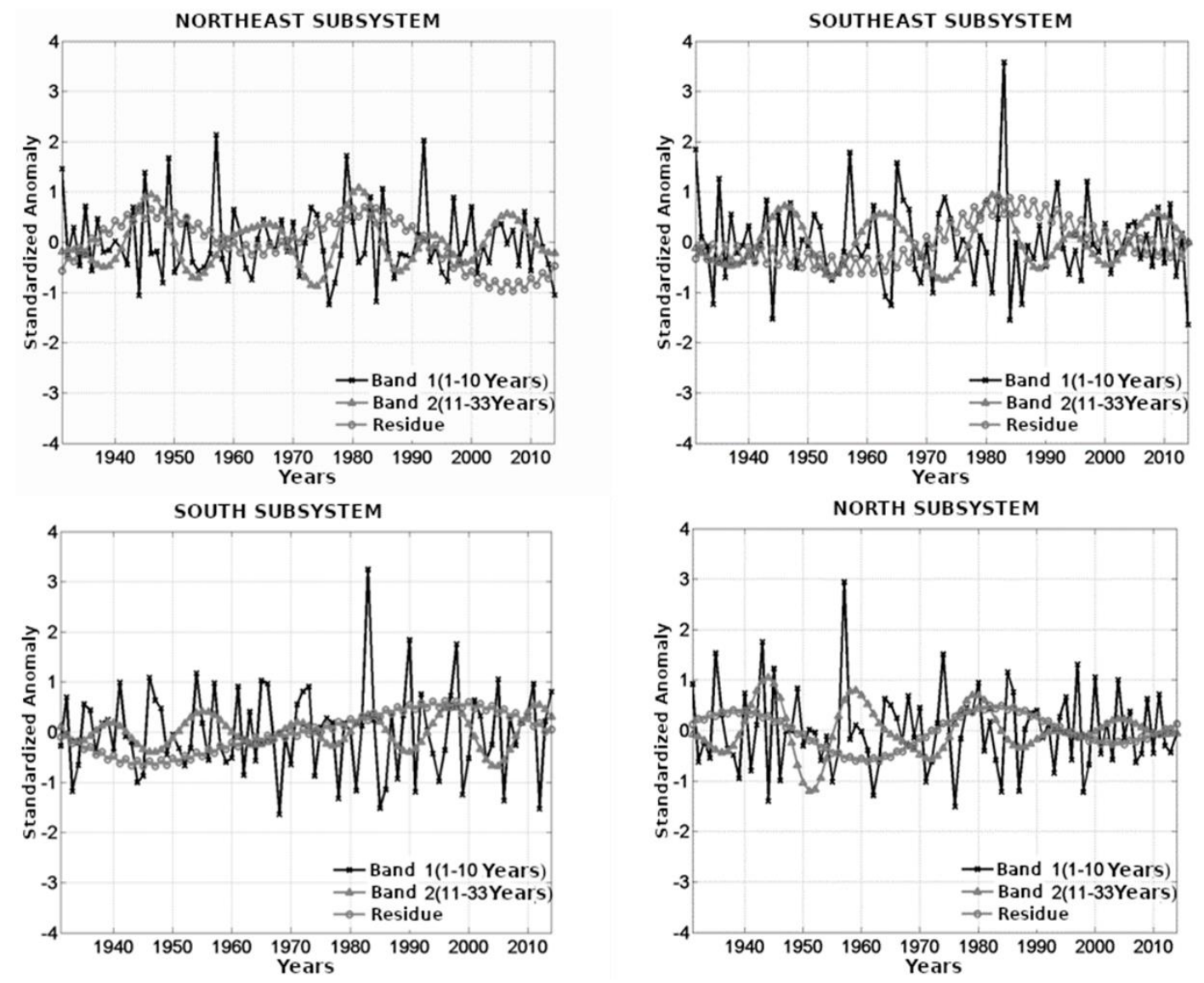

Figure 7. Wavelet analysis.

\subsection{Performance and Evaluation of the WAR model from 2005 to 2014}

The evaluation of the model is to verify if it is better than the climatology in the analyzed 10 years. It was performed by comparing the statistical distribution of the median of the scenarios generated by the WAR model compared to the statistical distribution of the 10 years evaluated (2005 to 2014). This NAE analysis is done concerning climatology. From then on, it obtains the likelihood ratio. Values greater than 1 indicate that the model was successful concerning climatology. Table 5 and Figure 8 show the likelihood ratio obtained by Equation 9. The model showed an improvement in the climatology for the Grande, Paranaíba, 
Paranapanema, São Francisco, Tocantins, Doce, Uruguay, Jacuí, Paraná, Tietê, Iguaçu and Paraíba do Sul Basins. However, for the Paraguai, Parnaíba, Amazonas, Atlântico Sul, Atlântico Suldeste and Atlântico Leste the model showed a worsening in the projection concerning Climatology.

Table 5. Likelihood Ratio- Performance.

\begin{tabular}{cc}
\hline Basin & Performance \\
\hline Paraguai, Paranaíba, Amazonas, Atlântico Sul, Atlântico Sudeste and & \\
Atlântico Leste, & $<1$ \\
Grande, Parnaíba, Paranapanema, São Francisco, Tocantins, Doce, Jacuí, \\
Paraná, Tiete, Uruguai, Iguaçu and Paraíba do Sul. & $>1$ \\
\hline
\end{tabular}

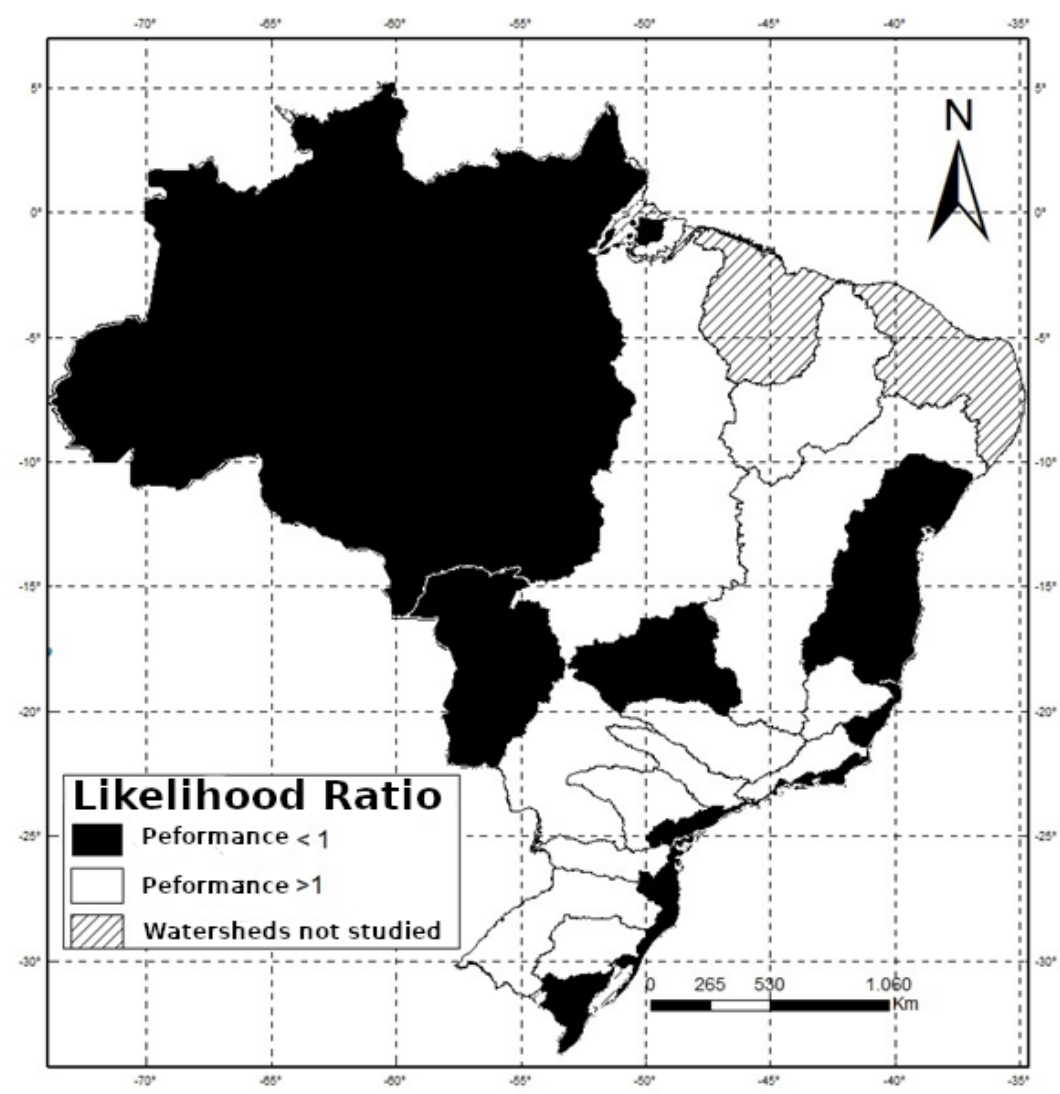

Figure 8. Likelihood ratio obtained between the WARs model and climatology for the SIN basins.

\subsection{Projection-based on the Medium Frequency Band}

As seen previously, the band of medium frequencies presents different significance for the analyzed basins. The Southeastern/Midwestern Subsystem presented significant variability in the 1980s. The low-frequency band remained constant until the 1960 period and in the period of its more energetic phase, between 1970 and 2000, it presented a direct correlation with the AMO's cold phase. The wavelets showed for Northeastern Subsystem that the years between 1940 and 1950 and in approximately 1980 are the periods responsible for a significant value in the variability of NAE and are their most energetic periods. The Northeastern subsystem presented variation in the low-frequency band of approximately 30 years. In the period 1931 to 1950, the time series shows the values of the standardized NAE index coincident with the periods of ODP in the cold phase. 
In the Southern Subsystem, the low-frequency band (Residual) showed oscillation in a long period, changing phase around 1970, with a considerable peak in the decade of 1990. The period between 1970 to 2000 coincided with the period of AMO in the phase cold. The Northern Subsystem showed significant variability around 1945 and 1980 in the bands; in those years the three bands were at coincident peak. The medium frequency band (11 to 33 years - Band 2) showed a gradual reduction of the amplitude of variation throughout the series. In the Northern and Southeastern Subsystem, there is a periodic oscillation in the low- frequency band with a period of approximately 30 years. It is possible that this behaviour is related to the PDO where the hot phase coincides with the less energetic periods and the cold periods coincide with the more energetic periods. It is also observed in the four graphs, a periodic oscillation in the medium frequency band with a period between 10 and 20 years.

\subsection{Projection: 2015 to 2024}

Figure 9 shows the NAE projections employing the WAR model for the period from 2015 to 2024 for the SIN basins. The Iguaçu and Atlântico Sudeste Basins indicate a greater possibility of a reduction in NAE by 2020 , while Parnaíba and Tocantins present a possible increase. These signals may be associated with the AMO and PDO signals.
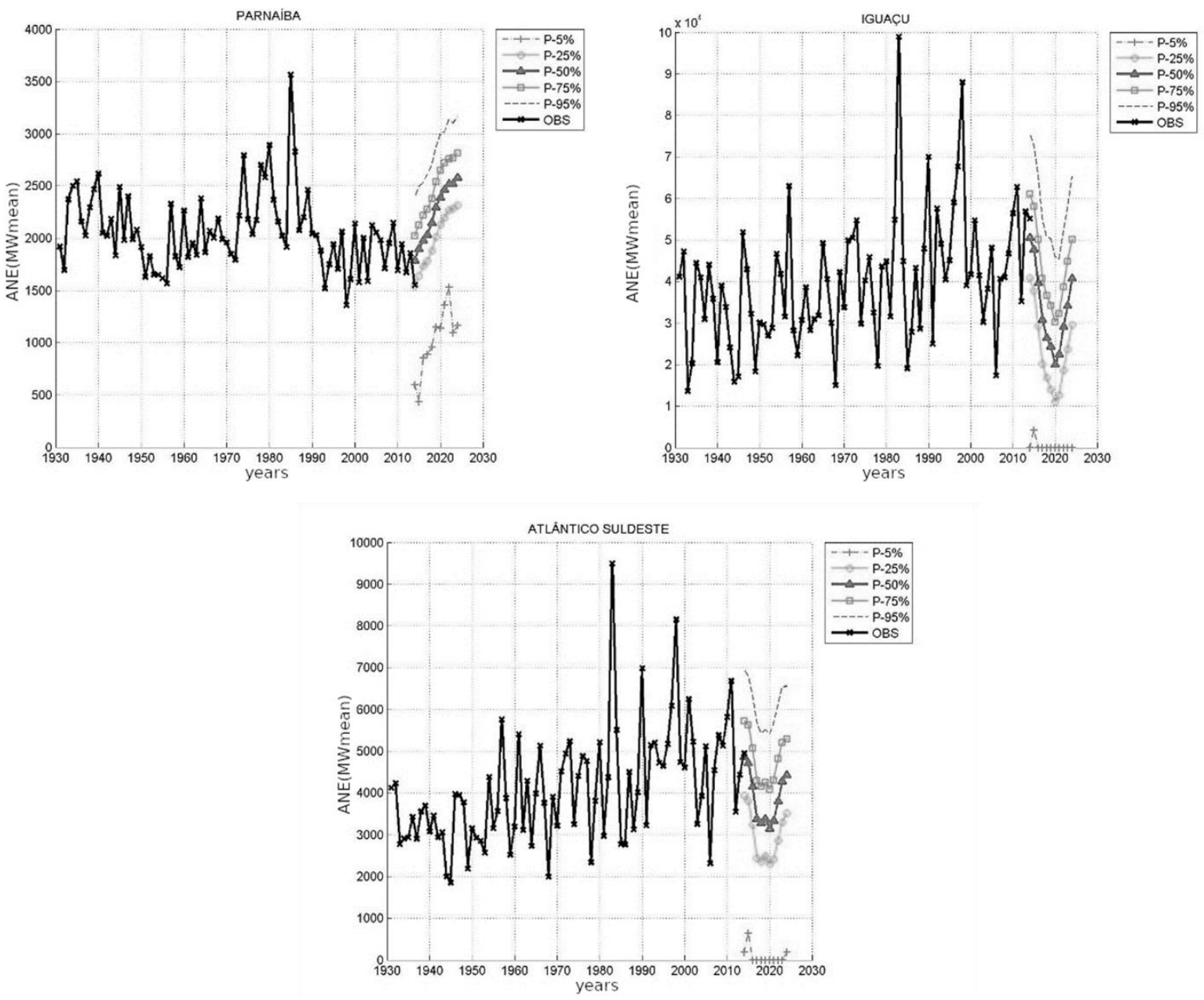

Figure 9. Projections of the WAR model for the period from 2015 to 2024.

\section{CONCLUSIONS}

The basins of the Atântico Sul, Atlântico Suldeste, Iguaçu, Jacuí, Paraguai, Paraná, Paranapanema, Tietê and Uruguai showed a positive trend, according to the method of Mann 
Kendall. It is observed that these basins predominantly belong to the Southern and Southeastern $\backslash$ Midwestern Subsystems. The basins of Amazonas, Grande, Paraíba do Sul, Paranaíba and São Francisco presented no significant trend. While the other basins studied, Atlântico Leste, Doce, Parnaíba and Tocantins presented a negative trend of NAE. The Southern and Southeast/Midwestern Subsystems indicated a positive trend and the Northeastern Subsystem showed a negative trend, while the Northern Subsystem presented a non-significant trend.

Güntner et al. (2007) analyzed monthly flow data and the capacity of the ENSO phenomenon, thus explaining the variability of the hydrological regime of the Southern American rivers and verified a significant correlation between ENSO variability and streamflow in most of South America. As the NAE is a direct product of the flow, this variability can be observed in this study. The patterns of identified variations of NAEs suggest a correlation with PDO.

\section{ACKNOWLEDGEMENTS}

To the research group Climate and energy planning (CLIPE). To the International Integration University of Afro-Brazilian Lusophony (UNILAB), to the Coordination of Improvement of Higher Level Personnel (CAPES), the Federal University of Ceará (UFC), the Cearense Foundation of Meteorology and Water Resources (FUNCEME).

\section{REFERENCE}

ANEEL. Banco de Informações de Geração. Capacidade de Geração do Brasil. Available at: www.aneel.gov.br. Access: 07 Sep. 2017.

ANDREOLI, R. V.; KAYANO, M. T. ENSO - related rainfall anomalies in South America and associated circulation features during warm and cold Pacific Decadal Oscillation regimes. International Journal Climatology. v. 25, n. 15, p. 2017-2030, 2005. https://doi.org/10.1002/joc.1222

BURN, D. H.; ELNUR, M. A. H. Detection of hydrologic trends and variability. Journal of Hydrology, v. 255, n. 1-4, p. 107-122, 2002. https://doi.org/10.1016/S00221694(01)00514-5

CANE, M. A. Decadal predictions in demand. Nature Geoscience, p. 231-232, 2010. https://doi.org/10.1038/ngeo823

CARVAlHO, L. M. V.; JONES, C.; LIEBMANN, B. The South Atlantic Convergence Zone: persistence, intensity, form, extreme precipitation and relationships with intraseasonal activity. Journal of Climate, v. 17, p. 88-108, 2004.

DANTAS, L. G. et al. Oscilação Decadal do Pacífico e Multidecadal do Atlântico no clima da Amazônia Ocidental. Revista Brasileira de Geografia Física, v. 5, n. 3, p. 600-611, 2012.

EMPRESA DE PESQUISA ENERGÉTICA. Anuário estatístico de energia elétrica 2011. Rio de Janeiro, 2011.

GÜNTNER, A.; STUCK, J.; WERTH, S.; DÖLL, P.; VERZANO, K.; MERZ, B. A global analysis of temporal and spatial variations in continental water storage. Water Resources Research, v. 43, n. 5, 2007. https://doi.org/10.1029/2006WR005247 
KODAMA, Y. M. Large-scale common features of subtropical precipitation zones (the Baiu Frontal Zone, the SPCZ, and the SACZ). Part II: Conditions for generating the STCZs. Journal of the Meteorological Society of Japan. v. 71, n. 2, p. 581-610, 1993. https://doi.org/10.2151/jmsj1965.70.4_813

KWON, H. H.; LALL, U.; KHALIL, A. F. Stochastic simulation model for nonstationary time series using an autoregressive wavelet decomposition: Applications to rainfall and temperature. Water Resources Research, v. 43, n. 5, 2007. https://doi.org/10.1029/2006WR005258

LÁZARO, Y. M. C. Mudança climática no nordeste do Brasil, Amazônia e Bacia do Prata: avaliação dos modelos do IPCC e cenários para o século XXI. 2011. 89 f. Dissertação (Mestrado em Engenharia Civil: Recursos Hídricos) - Centro de Tecnologia, Universidade Federal do Ceará, Fortaleza, 2011.

MANTUA, N. J. et al. A Pacific Interdecadal Climate Oscillation with impacts on salmon production. Bulletin of the American Meteorological Society, v. 78, p. 1069-1079, 1997. https://doi.org/10.1175/1520-0477(1997)078\%3C1069:APICOW\%3E2.0.CO;2

MOREIRA JUNIOR, F. de J. M.; CATEN, C, S. Estudo sobre o efeito da Autocorrelação de Modelos AR(1) no Controle Estatístico de Processo. In: ENCONTRO NACIONAL DE ENGENHARIA DE PRODUÇÃO, 24., 2004, Florianópolis. Anais[...] Florianópolis: ABEPRO, 2004.

MORETTIN, P. A. Econometria financeira: um curso de séries temporais financeira. São Paulo: Edgard Blücher, 2008.

NASCIMENTO JÚNIOR, L.; SANT'ANNA NETO, J. L. Contribuição aos estudos da precipitação no estado do Paraná: a oscilação decadal do Pacífico - ODP. Raega - O

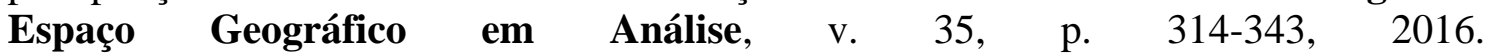
http://dx.doi.org/10.5380/raega.v35i0.42048

OPERADOR NACIONAL DO SISTEMA ELÉTRICO. Programa mensal de operação PMO: relatório de previsão de vazões e geração de cenários de afluências. 2012. Available at: http://www.ons.org.br/conheca_sistema/o_que_e_sin.aspx. Access: 15 May 2016.

RAMOS, T. P. Modelo individualizado de usinas hidrelétricas baseado em técnicas de programação não linear integrado com o modelo de decisão estratégica. 2011. Dissertação (Mestrado em Energia) - Universidade Federal de Juiz de Fora, Juiz de Fora, 2011.

SILVA, D. F. Influência Interdecadal (ODP e OMA) nas Cotas do Rio São Francisco. Revista Brasileira de Geografia Física, v. 6, n. 6, p. 1529-1538, 2013.

SILVA, D. F.; GALVÍNCIO, J. D. et al. Influência da variabilidade climática e da associação de fenômenos climáticos sobre sub-bacias do rio São Francisco. Revista Brasileira de Ciências Ambientais, n. 19, p. 46-56, 2011.

SILVEIRA, C. S. Modelagem integrada de meteorologia e recursos hídricos em múltiplas escalas temporais e espaciais: aplicação no Ceará e no setor hidroelétrico brasileiro. 2014. 352 f. Tese (Doutorado em Recursos Hídricos) - Centro de Tecnologia, Universidade Federal do Ceará, Fortaleza, 2014.

TORRENCE, C.; COMPO, G. P. A Practical Guide to Wavelet Analysis. Bulletin of American Meteorological Society, v. 79, p. 61-78, 1998. https://doi.org/10.1175/15200477(1998)079\%3C0061:APGTWA\%3E2.0.CO;2 